\title{
Duygusal Zekânın Liderlik Üzerine Etkisi: Okul Yöneticileri Üzerine Bir Araştırma ${ }^{1}$
}

\author{
Dr. Yakup KARADAVUT* \\ Kara Kuvvetleri Komutanlı̆̆ı, Ankara / Türkiye, \\ yakupkaradavut@hotmail.com, ORCID: 0000-0003-4471-0808 \\ Dr. Şahin ÇETIN \\ Maltepe Üniversitesi, Eğitim Fakültesi, Marmara Eğitim Köyü, Maltepe / İstanbul / Türkiye, \\ sahincetin@maltepe.edu.tr, ORCID: 0000-0003-2757-4584
}

\section{$\ddot{\mathbf{O} z}$}

Araştırmanın amacı, okul yöneticilerinin duygusal zekâ yeterliklerini incelemek, duygusal zekânın cinsiyete göre farklılaşıp farklılaşmadığını ve dönüşümcü ve etkileşimci liderliği ne düzeyde yordadığını belirlemektir. Çalışmaya İzmit ili ve ilçelerinde ilköğretim ve ortaögretim düzeyindeki okullarda görev yapan 303 okul yöneticisi katılmıştır. Araştırmanın sonuçlarına göre, kadın okul yöneticilerinin özbilinç ve sosyal bilinç yeterlikleri erkek okul yöneticilerine kıyasla anlamlı düzeyde yüksektir. Duygusal zekâ yeterliklerinden başarma dürtüsü ve duygusal özbilinç dönüşümcü liderliğin anlamlı bir yordayıcısıdır. Benzer şekilde; uyumluluk, başkalarını geliştirme ve çatışma yönetiminin etkileşimci liderliği anlamlı düzeyde yordadığı bulunmuştur. Çalışmanın son bölümünde bulguların kuram ve uygulamaya yönelik sonuçları tartışılmış ve araştırmacılara yönelik öneriler sunulmuştur.

Anahtar Kelimeler: Duygusal zekâ; Dönüşümcü liderlik; Etkileşimci liderlik.

\footnotetext{
${ }^{1} \mathrm{Bu}$ çalışma Dr. Yakup Karadavut'un doktora tezinden üretilmiştir.

* Sorumlu Yazar. Tel: +90 2166261050 - 2215

(C) 2018 Kalem Eğitim ve Sağlık Hizmetleri Vakfı. Bütün Hakları Saklıdır. 


\title{
The Effect of Emotional Intelligence on Leadership:
}

\section{An Empirical Study on School Administrator}

\begin{abstract}
The purpose of this study was to find out the association between school administrators' emotional intelligence and leadership. To this end, we investigated whether school administrators' emotional intelligence varied according to gender and to what extent their transformational/transactional leadership was accounted for by emotional intelligence. 303 school principals and vice principals working at primary and secondary level public schools in and around Izmit participated in the study. Female vice principals and principals were found to have higher levels of self and social awareness than their male colleagues. Achievement and emotional self awareness significantly predicted transformational leadership whereas adaptability, developing others and conflict management were significant predictors of transactional leadership. Implications of findings for theory and practice were discussed and directions for future research were laid out in the end of the study.
\end{abstract}

Keywords: Emotional intelligence; Transformational leadership; Transactional leadership.

\section{Extended Summary}

Emotional intelligence is defined as the ability to monitor one's own and other people's emotions, discriminate between different emotions, and to use this knowledge to guide thinking and behavior (Goleman, 2005a). Current study is based on the model of emotional intelligence proposed by Boyatzis, Goleman and Rhee (2000) and defines the concept as a set of competencies, a combination of abilities and traits. According to this model, emotional intelligence is made up of four core skills that pair up under two primary competencies: personal competence and social competence. Personal competence focuses upon the individual and is made up of self-awareness and self-management skills. Personal competence is defined as the ability to stay aware of one's emotions and manage behavior and tendencies. Self-awareness is the ability to perceive and stay aware of one's own emotions as they happen. Self-management is the ability to use awareness of emotions to direct behavior. 
Social competence is the ability to understand other people's moods, behavior, and motives and use this understanding to improve relationships. It is made up of social awareness and relationship management skills. Social awareness is about picking up on other people's emotions and understand what is going on. Relationship management is the ability to use awareness of one's own and others' emotions to manage interactions successfully.

Emotional intelligence is of critical importance for leaders. Effective leadership calls for an awareness of and ability to manage other people's emotions. Research has shown that emotional intelligence is closely related with leader effectiveness (George, 2000; Goleman, 2005a; Higgs and Rowland, 2001) and the higher the level of the leader the more important is emotional intelligence (Dulewicz and Higgs, 2003; Goleman, 2005a).

Recently the most widely researched leadership model in leadership literature has been transformational and transactional leadership. Transformational leaders stimulate followers to look beyond their self interest for the sake of the mission and vision of the organization and view task from a new perspective. Followers' confidence levels are raised and their needs broadened. Such total engagement (emotional, intellectual and moral) encourages followers to perform beyond expectations. Bass and his colleagues identified four behavioral components of transformational leadership; idealized influence, inspirational motivation; intellectual stimulation and individualized consideration. Transactional leaders on the other hand develop a relationship of mutual exchange with followers. Three behavioral components of transactional leadership have been defined; contingent reward, management by exception (active), and management by exception (passive). The model also identified a non-leadership factor indicating the absence of leadership named laissez-faire.

Research on the relationship between emotional intelligence and transformational leadership (e.g., Barbuto and Burbach, 2006; Barling, Slater and Kelloway, 2000; Corona, 2010; Gardner and Stough, 2002; Leban and Zulauf, 2004; Lindebaum and Cartwright, 2010; Mandell and Pherwani, 2003; Rajagopalan, 2009) found significant positive associations between the two constructs. Some emotional competencies were found to be stronger predictors of leadership whereas the relationship between intellectual stimulation and emotional intelligence was somewhat weaker or insignificant (Barling, Slater ve Kelloway, 2000). 
Main purpose of current research is to explore the relationship between emotional intelligence and transformational/transactional leadership. Additionaly we aim to study emotional intelligence levels of principals and vice principals and see if (vice) principals' emotional intelligence varies according to gender.

\section{Method}

303 principals and vice principals working at primary and secondary level schools in downtown İzmit and provinces participated in the study. Cluster sampling method whereby each province was treated as a subuniverse was employed to identify schools to be involved. How much each province was to be represented in the sample was identified according to the percentage of (vice) principals in the universe of (vice) principals in İzmit. Schools to be involved in each province was randomly selected then. Participants filled a multifactor leadership questionnaire assessing to what extent they perceived their leadership transformational/transactional leadership and an emotional intelligence questionnaires assessing their emotional competencies. Data were analyzed using SPSS and LISREL software.

\section{Results}

Female vice principals and principals were found to have higher levels of emotional competence than male (vice) principals. Especially their self and social awareness were significantly higher than that of their male colleagues. Emotional competence was found to be a significant predictor of transformational (46\%) and transactional leadership (33\%).

\section{Conclusion}

Achievement and emotional self awareness significantly predicted transformational leadership whereas adaptability, developing others and conflict management were significant predictors of transactional leadership. Achievement orientation concerns an awareness of one's own emotions and the competence in expressing them socially acceptable ways. Interestingly enough, self confidence was a negative predictor of both transformational and transactional leadership.

Adaptability, developing others and conflict management were significant predictors of transactional leadership whereas self confidence and change catalyst had a negative effect. 


\section{Giriş}

Duygular, liderliğin ve onun özünü oluşturan etkileme sürecinin merkezinde yer alır. Bununla birlikte, liderlik çalışmalarında liderliğin duygusal boyutu uzun bir süre görmezden gelinmiştir. Liderlerin özellikleri, davranışları, liderlik stilleri ve karar alma biçimleri ayrıntılı olarak incelenmiş; ancak duyguların liderlik sürecindeki rolü üzerinde sistematik olarak durulmamıştır. Bu ihmalin en başta gelen nedenlerinden biri, Batı düşüncesinin özellikle aydınlanma çağı ile birlikte artan ölçüde akılcı bir nitelik kazanmaya başlamasıdır. Modernitenin en önemli uğrağını oluşturan 18. yüzyılda başladığı ve etkilerinin halen sürdüğü kabul edilen aydınlanma çağı, insan aklını egemen kılması ve tüm toplumsal ilişkileri ve kurumları akılcı esaslar üzerine oturtmayı hedeflemesi nedeniyle akıl çağı olarak da adlandırılmaktadır (Çiğdem, 1997).

Duyguların liderlik sürecindeki rolüne ilişkin ilk çalışmalar 1990'lı yıllarda gerçekleştirilmeye başlanmıştır (George, 2000). George ve Bettenhausen (1990) liderlerin olumlu duygu durumları (moods) ile grup üyelerinin prososyal davranışları arasında olumlu, işgücü devri arasında ise olumsuz bir ilişki olduğunu ortaya koymuştur. George (1995'ten akt; George, 2000) ise iş yerinde olumlu duygu durumları tecrübe eden liderlerce yönetilen satış ekiplerinin, olumsuz duygu durumları deneyimleyen liderlerin ekiplerine kıyasla daha nitelikli müşteri ilişkileri hizmeti verdiklerini göstermiştir.

Duyguların farkında olma ve onları yönetme yetisinin bilimsel çalışmalarda da kullanılabilmesine imkân verecek ilk (ve halen en yaygın) model duygusal zekâ olmuştur. Duygusal zekâ kavramı ilk olarak 1990 yılında Mayer, DiPaolo ve Salovey (1990) ile Salovey ve Mayer (1990) tarafindan kullanılmıştır.

\section{Duygusal Zekâ}

Mayer ve Salovey; duygusal zekâyı "bireyin kendisinin ve diğerlerinin duygularını izleme, bunlar arasında ayrım yapma ve bu süreçten elde ettiği bilgiyi, düşünce ve davranışlarında kullanabilme yeteneğ i" olarak tanımlamıştır (Salovey ve Mayer, 1990, s.189). Kavram, Daniel Goleman'in 1995 yılında yayımladığı Duygusal Zekâ kitabı ile büyük ilgi çekmiş ve popülerlik kazanmıştır. İzleyen yıllarda araştırmacılar duygusal zekâyı yaygın bir biçimde incelemiş ve farklı duygusal zekâ tanımlarına dayanan farklı modeller geliştirmiştir. 
Mevcut çalışmada esas alınan duygusal zekâ modeli Boyatzis, Goleman ve Rhee (2000) tarafından geliştirilmiştir. Model, duygusal zekâyı yetenek ve kişilik özelliklerin birleşiminden oluşan duygusal yeterlikler bütünü olarak tanımlamakta ve ikisi kişisel (özbilinç ve özyönetim), ikisi ilişkisel/sosyal (sosyal bilinç ve ilişkisel yönetim) olmak üzere, dört yeterlik altında toplam on sekiz alt yeterlikten oluşmaktadır.

Kişisel yeterlikler bireyin kendi duygularını bilmesi ve yönetmesi ile ilgilidir ve özbilinç ile özyönetim yeterliklerinden oluşmaktadır. Özbilinç; kişinin kendi duyguları, güçlü ve zayıf yanları, kapasitesi, değerleri ve dürtüleri hakkında derin bir anlayışa sahip olması demektir. Özbilinci güçlü olan bireylerin kendilerini ölçüp biçme eğilimleri kuvvetlidir. Bu bireyler gerçekçi ve kendileri hakkında dürüsttür; hangi yönde ve ne amaçla ilerlediklerini bilirler ve kararları değerleriyle örtüştügü için işlerinden enerji alırlar. Özbilinç; duygusal özbilinç, isabetli özdeğerlendirme ve özgüven olmak üzere üç alt yeterliği kapsamaktadır (Goleman, Boyatzis ve McKee, 2002). Duygusal zekânın ikinci kişisel yeterliği olan özyönetim, bireyin duygular1n1, güdülerini, sahip olduğu kaynakları yönetebilme (Poskey, 2006), kaygı ve öfke gibi sıkıntı verici durumları düzenleme ve duygusal dürtülere hâkim olabilme yeteneğidir (Goleman, 2007). Özyönetim; duygusal özdenetim, saydamlık, uyumluluk, başarma dürtüsü, inisiyatif ve iyimserlik alt boyutlarını kapsamaktadır (Goleman, 1998).

İlişkisel (sosyal) yeterlikler ise bireyin diğer bireylerle ilişkilerini nasıl idare ettiği ile ilişkilidir ve sosyal bilinç ile ilişki yönetimi yeterliklerini kapsamaktadır. Sosyal bilinç, ilişkilerin nasıl ele alındığı ile ilişkilidir ve empati, örgütsel bilinç ve hizmet yeterliklerini içerir. İlişki yönetimi ise bireyin etkili bir ilişki kurmasını, karşısındakinin duygularını etkilemesini veya duygularını onun duygularıyla uyumlu hale getirmesini ifade etmektedir (Goleman, 1998). Başkalarını geliştirmek, esin verici liderlik, etkileme, çatışma yönetimi, değişim katalizörlüğü ile ekip çalışması ve imece yeterlikleri ilişki yönetimi oluşturan alt yeterliklerdir (Goleman, Boyatzis ve McKee, 2002).

Duygusal zekâ konusunda yaygın bir biçimde tartışılan meselelerden biri duygusal zekânın cinsiyete göre ne şekilde farklılaştığıdır. Genel olarak kadınların daha yüksek düzeyde duygusal zekâ yeterliğine sahip olduğu kabul edilmektedir. Çoğunluğunu lise ve lisans düzeyindeki öğrencilerin oluşturduğu farklı örneklem grupları üzerinde yapılan çalışmalarda elde edilen 
sonuçlar da bu yöndedir (Ciarrochi, Chan ve Caputi, 2000; Dawda ve Hart, 2000; Extremera, Fernandez-Berrocal ve Salovey, 2006; Mayer, DiPaola ve Salovey, 1990; Wolf, 2005). Yeterliklerin cinsiyete göre farklılaşması konusunda ise birbiri ile çelişen sonuçlar bulunmaktadır. Kadınların ilişki yönetimi (Bar-On, Brown, Kirkcaldy ve Thome, 2000) sosyal bilinç (Wolf, 2005); uyumluluk ve hizmet yeterlikleri (Cavallo ve Brienza, 2004) ile duyguları algılama yeterliği bakımından erkeklerden daha başarılı oldukları (Ciarrochi, Chan ve Caputi, 2000; Mayer ve Geher, 1996; Wong ve Law, 2002), ancak duygularından daha fazla şüphe duydukları ve aklı daha geri planda tuttukları (Quader, 2011) belirtilmektedir. Erkeklerin ise özellikle stresle başa çıkmada daha başarılı olduğu ifade edilmektedir (Bar-On ve ark., 2000).

Duygular ve duygusal zekâ, temelde sosyal bir etkileme süreci olarak tanımlanan liderliğin önemli bir yanını oluşturmaktadır. Duygularını ifade edebilen, diğer bireylerin duygularını anlayabilen ve onlarla empati kurabilen liderler bu konuda yetersizlik sergileyen liderlere göre daha etkilidir (Antonakis, Ashkanasy ve Dasborough, 2009). Özellikle özgüven, başkalarını geliştirme, empati, hizmet ve değişim katalizörlüğü gibi duygusal zekâ yeterliklerinin lider performansı üzerinde etkili olabileceği kabul edilmektedir (Cavallo ve Brienza, 2004).

\section{Dönüşümcü ve Etkileşimci Liderlik}

Liderlik alanyazınında son yıllarda en çok ilgi çeken ve üzerinde en s1k durulan kuramların başında dönüşümcü ve etkileşimci liderlik gelmektedir. Dönüşümcü liderlik kavramı ilk olarak McGregor Burns tarafından tanımlanmıştır. Burns'e göre dönüşümcü liderler takipçilerin ahlâkî değerlerine hitap ederek onların etik meselelere ilişkin bilincini artırmaya, onların enerjilerini ve kaynaklarını harekete geçirerek örgütlere yeni bir biçim vermeye çalışır. Etkileşimci liderler ise takipçilerin kişisel çıkarlarına ve karş1lıklı faydaya hitap ederek onları motive eder. Daha sonra kuramın farklı versiyonları geliştirilmiş ancak Bass (1985, 1996'dan akt; Yukl, 2012) tarafından geliştirilen versiyonu liderlik araştırmalarını diğerlerinden daha fazla etkilemiştir. Bass'e göre (1985'ten akt; Yukl, 2012), dönüşümcü ve etkileşimci liderlik birbirinden ayrıdır; ancak birinin varlığı diğerini dışarıda b1rakmaz. Etkileşimci liderlik, takipçilerin liderin isteklerine uyması ile sonuçlanacak bir takas sürecini içerir fakat görev hedefleri konusunda bir heves veya bağl1lık yaratmaz. Buna karşın, dönüşümcü liderlikle, takipçiler 
lidere karşı güven, takdir, sadakat ve saygı hissederler ve beklediklerinden daha fazlasını yapmalarını sağlayacak bir motivasyon duyarlar. Lider, takipçileri; (1) işten elde edilecek sonucun öneminin daha çok farkında olmalarını sağlayarak, (2) onları örgüt ya da takım uğruna kendi kişisel çıkarlarını aşmaya teşvik ederek ve (3) üst düzey ihtiyaçlarını harekete geçirerek değiştirir ve güdüler (Yukl, 2012). Bu süreçte lider de bu moral dönüşümü gerçekleştiren bir faile (agent) dönüşmüştür (Krishnan, 2005). Bass (1990), dönüşümcü liderliği idealleştirilmiş etki, esin verici motivasyon, entelektüel uyarım ve bireysel ilgi olmak üzere dört alt boyutta tanımlamıştır.

Etkileşimci liderliğin temelinde ise 'koşullu ödüle dayanan bir takas' (Omar, Zainal, Omar ve Khairudin, 2009) ilişkisi vardır. Dönüşümcü liderlerin tersine etkileşimci liderler astların kısa vadeli somut (örneğin fiziksel ve güvenlik ihtiyaçları gibi) ihtiyaçlarına odaklanır. Astlardan beklentilerini ve bu beklentilerin karşılanması durumunda astların neler elde edeceğini açıklarlar (Den Hartog, Van Muijen ve Kopman, 1997). Ayrıca astların göreve odaklanabilmesi için onlara yapıcı geri bildirimde bulunur ve görevin tamamlanması durumunda övgü, tanınma ve parasal ödüller gibi dışsal ödüller sağlarlar. Bunun sonucunda çalışanlar iş rollerini ve lider ile örgütün kendilerinden neler beklediğini anlarlar ve beklentileri karşılayabilecekleri, ortak olarak değer verilen sonuçları elde edebilecekleri konusunda bir özgüven geliştirirler (Omar ve ark., 2009).

Etkileşimci liderlik kuramının orijinal biçiminde iki tür etkileşimsel davranış tanımlanmıştır; koşullu ödül ve istisnalarla pasif yönetim. Koşullu ödül davranışı, astların ödül hak etmek için ne tür başarılar göstermesi gerektiğini açıklamak ve onları güdülemek için birtakım özendiriciler kullanmayı kapsar. İstisnalarla pasif yönetim kabul edilebilir performans standartlarından belirgin sapmalar karşısında koşula bağlı cezaların ve diğer düzeltici davranışların kullanımıdır. Daha sonra kuramda bu iki boyuta istisnalarla aktif yönetim (hata arama ve hataları önlemek için kurallar konusunda polislik yapma) ile serbest bırakıcı liderlik (problemleri ve astların ihtiyaçlarını göz ardı etme) davranışları eklenmiştir. Serbest bırakıcı liderlik aslında etkili liderliğin olmamasıdır ve kuramın revize edilmiş versiyonunda ayrı bir liderlik biçimi olarak tanımlanmaktadır (Yukl, 2012).

Bir liderin astlarını etkileyerek onların ortak bir vizyona ve amaca odaklanmalarını sağlaması ancak duyguları etkili bir biçimde kullanabilmesi ile mümkündür. Duygusal yeterlikleri gelişmiş liderler, astlarının bireysel 
özellikleri ile ihtiyaçlarının farkındadır ve onlara içten bir ilgi gösterir. Başkalarının duygularına yönelik farkındalık bu liderlerin astlarla daha etkili iletişim kurmasına ve onların inanç, düşünce ve kabullerini etkilemesine yardım edebilir (George, 2000).

Araştırmalar duygusal zekâ ile lider etkililiği arasında anlamlı ilişkiler olduğunu (George, 2000; Goleman, 2005a; Higgs ve Rowland, 2001; Packard, 2008; Samad, 2009) ve liderin konumu yükseldikçe duygusal zekânın öneminin arttı̆̆ını göstermektedir (Dulewicz ve Higgs, 2003; Goleman, 2005a). Bu konuda Türkiye'de gerçekleştirilen araştırmalarda da bu yönde sonuçlar elde edilmiştir. Örneğin Acar (2002) tarafından banka müdür ve müdür yardımcıları üzerinde gerçekleştirilen araştırmada duygusal zekâ ile ilişki odaklı liderlik arasında güçlü ve olumlu bir ilişki bulunmuştur (Acar, 2002). Yönetici hemşireler üzerinde yapılan diğer bir çalışmada da duygusal zekâ ile liderlik davranışlarından vizyonu uygulamaya koyma ve takım odakl1lık arasında kuvvetli bir ilişki bulunmuştur (Kuşaklı, 2008). Okullar bağlamında ise okul yöneticilerinin duygusal zekâ yeterliklerinin birçok alt boyutu ile ilişki odaklı ve görev odaklı liderlik arasında anlamlı ilişkiler bulunmuştur (İşliel, 2013).

Dönüşümcü/etkileşimci liderlik bağlamında düşünüldüğünde duygusal zekâ ile özellikle dönüşümcü liderlik arasında önemli kesişme alanlarının bulunabileceği ifade edilebilir. Çünkü dönüşümcü liderlik, takas ve karş1lıklı fayda odaklı bir süreç olan etkileşimci liderlikten farklı olarak, liderin idealize edilen özellik/davranışlar sergileyerek izleyicilerini daha yüksek bir bilinç/davranış düzeyine çıkarmasına dayanmaktadır. Duygusal zekânın dönüşümcü ve etkileşimci liderlik üzerindeki etkisini karşılaştıran çalışmalarda elde edilen sonuçlar bu yargıyı desteklemekte, duygusal zekânın dönüşümcü liderliği yordama düzeyinin etkileşimci liderliğe kıyasla daha yüksek olduğunu göstermektedir (Jerome, 2009; Rajagopalan, 2009). Duygusal zekâ ile dönüşümcü liderlik arasındaki ilişkiyi inceleyen çalışmalarda (örneğin Barbuto ve Burbach, 2006; Barling, Slater ve Kelloway, 2000; Corona, 2010; Gardner ve Stough, 2002; Leban ve Zulauf, 2004; Lindebaum ve Cartwright, 2010; Mandell ve Pherwani, 2003; Rajagopalan, 2009) iki değişken arasında anlamlı pozitif ilişki bulunduğu sonucuna ulaşılmıştır. Farklı çalışmalarda bazı alt boyutların dönüşümcü liderlik üzerindeki yordayıcı etkisinin diğer alt boyutlara göre daha güçlü olduğu bulunmuştur. Genel olarak entelektüel uyarım ile duygusal zekâ arasındaki ilişkinin zayıf ya da 
anlamsız olduğu söylenebilir (Barling, Slater ve Kelloway, 2000). Türkiye'de farklı türlerdeki örgütlerde gerçekleştirilen çalışmalarda da (Çakar ve Arbak, 2003; Erkuş ve Günlü, 2008; Özer, 2010) benzer sonuçlar elde edilmiştir. Bu çalışmalarda duygusal zekânın dönüşümcü liderlik alt boyutlarından özellikle bireysel ilgi ve esin verici motivasyonu güçlü bir biçimde yordadığ1 (Çakar ve Arbak, 2003) duygusal zekâ yeterliklerinden ise özellikle kişiler arası ilişki yeterliği (Erkuş ve Günlü, 2008; Özer, 2010) ile özyönetim yeterliğinin (Özer, 2010) dönüşümcü liderlik sürecinde önemli olduğu saptanmıştır. Bu açıdan duygusal zekânın etkileşimci ve dönüşümcü liderliğin muhtemel öncüllerinden olabileceği değerlendirilebilir.

Kişiler arası ilişkileri yönetebilmek, ilişkilerden kaynaklanan zor durumlarla ve problemlerle başa çıkabilmek için okul yöneticilerinin duygusal zekâ yeterliklerine gereksinimi yüksek düzeydedir. Buna rağmen Türkiye'de okul yöneticilerinin duygusal zekâ yeterlikleri, duygusal zekâ yeterliklerinin cinsiyete göre nasıl farklılaştığ1 ve duygusal zekâ-liderlik ilişkisinin düzeyi konusunda alanyazında bir boşluk olduğu gözlemlenmektedir. Bu bağlamda mevcut araştırma, aşağıdaki iki temel soruya ve bu sorularla ilişkili üç alt soruya yanıt aramaktadır:

1. Okul yöneticilerinin duygusal zekâ yeterlikleri ne düzeydedir?

a. Okul yöneticilerinin duygusal zekâ yeterlikleri cinsiyete göre farkl111k göstermekte midir?

2. Okul yöneticilerinin duygusal zekâ yeterlikleri

a. dönüşümcü liderliğii,

b. etkileşimci liderliği ne düzeyde yordamaktadır?

Duygusal zekânın okul yöneticilerinin liderliği üzerindeki etkisinin anlaşılması birçok bakımdan önemlidir. Yönetici rollerinin karmaşıklı̆̆ının artmaya başlaması ile bütün örgütlerde olduğu gibi okullarda da liderlik önem kazanmıştır. Okul liderinin başarılı olması farklı insanlarla olumlu ilişkiler kurabilmesine bağlıdır. Bu da ancak liderlerin kendi duygularıyla ve başkalarının duygularıyla etkili bir ilişki kurabilmesi ile mümkündür. Araştırmalar da okul yöneticilerinin özellikle zor durumlarla başa çıkma, kişilerarası ilişkileri yönetme ve problem çözme gibi durumlarda duygusal zekâ yeterliklerine gereksinim duyduklarını göstermektedir (Spaeth, 2007). Duyguların yoğun olarak ön planda olduğu sorunlarla başa çıkabilen, özbilince 
sahip, kendilerine ve başkalarına ilham verebilen, inisiyatif kullanabilen, hoşgörü, empati ve esneklik gösterebilen (Weinberger, 2003) okul yöneticilerinin okulda öğrenme ve öğretme odaklı olumlu bir iklim ve kültür oluşturma, öğretmenleri örgütsel hedefleri gerçekleştirme yönünde motive etme ve başarıya ulaşma olasılığı daha yüksektir.

Duygusal zekâ ile okul yöneticilerinin liderliği arasındaki ilişkiyi inceleyen araştırmaların artması hem bu iki kavram arasındaki ilişkinin anlaşılması hem de okullardaki liderlik potansiyelinin geliştirilmesi açısından gereklidir. Bu çalışma ile alanyazın bu yönde bir katkı sağlanması umut edilmektedir.

\section{Araştırmanın Modeli}

\section{Yöntem}

$\mathrm{Bu}$ araştırmada okul yöneticilerinin duygusal zekâ yeterliklerinin belirlenmesi amacına yönelik olarak tekil tarama modeli, duygusal zekâ yeterliklerinin liderliği yordama düzeyinin belirlenmesinde ise ilişkisel tarama modeli kullanılmıştır. Karasar'a göre (2007) tekil tarama modeli değişkenlerin tür ve miktar gibi niteliklerinin betimlenmesine dayanan araştırma modelidir. İlişkisel tarama modelinde ise iki ve daha çok sayıdaki değişken arasında birlikte değişimin varlığ 1 ve/veya derecesinin belirlenmesi amaçlanır. İlişkisel tarama modelinde var olanın belli standartlara uyan ölçülerini bulmaktan çok, durumlar arasındaki ilişkinin belirlenmesi amaçlanmaktadır.

\section{Evren ve Örneklem}

Araştırmanın evrenini, 2013-2014 eğitim-öğretim yılı itibari ile Kocaeli ilinin merkez ilçe ile birlikte 12 ilçesindeki ilköğretim ve ortaöğretim düzeyindeki 545 kamu okulunda görev yapan 1003 okul yöneticisi (müdür ve müdür yardımcıları) oluşturmaktadır.

Örneklem büyüklüğünün belirlenmesinde kuramsal örneklem büyüklükleri tablosundan yararlanılmış ve 280 ilk ve ortaöğretim okulu yöneticisinin 1003 yöneticiden oluşan evreni, $\alpha=.05$ anlamlılık ve $\% 5$ hata payı düzeyinde temsil edebileceği varsayılmıştır (Can, 2014). Ancak ölçeğin uygulama esnasında ve sonrasında yaşanabilecek muhtemel kayıplar nedeni ile örneklem sayısının \%10 arttırılarak örneklem büyüklüğünün 308 yöneticiden oluşturulmasına karar verilmiştir. Araştırmada "tabakalı örnekleme" yolu ile örneklem seçimine gidilmiştir. Her bir ilçe bir alt evren olarak kabul edilmiştir. Örneklemin ilçelere göre dağılımı belirlenirken her ilçedeki toplam yönetici sayısının, evren içerisindeki oranı belirlenmiş ve her ilçe evren içe- 
risinde hangi oranda temsil ediliyorsa örneklem içerisinde de aynı oranda temsil edilmesi hedeflenmiştir. Her bir ilçeden okullar basit tesadüfi yöntemle belirlenmiştir. Tablo 1'de örneklemi oluşturan okulların ve okul yöneticilerinin dağılım oranları verilmiştir.

Tablo 1. Katılımc1ların Alt Evrenlere Göre Dağılımı1

\begin{tabular}{lcccc}
\hline Alt Evren & \multicolumn{2}{c}{ Okul } & \multicolumn{2}{c}{ Yönetici } \\
\hline İlçeler & N & \% & N & \% \\
\hline İzmit & 23 & 19 & 67 & 21.8 \\
Başiskele & 8 & 6.7 & 20 & 6.5 \\
Gölcük & 11 & 9 & 28 & 9.1 \\
Karamürsel & 5 & 4.2 & 11 & 3.6 \\
Kartepe & 9 & 7.4 & 20 & 6.5 \\
Derince & 11 & 9 & 28 & 9.1 \\
Körfez & 12 & 9.9 & 29 & 9.4 \\
Kandıra & 4 & 3.3 & 12 & 3.9 \\
Gebze & 17 & 14 & 45 & 14.6 \\
Çayırova & 8 & 6.7 & 19 & 6.2 \\
Darıca & 10 & 8.3 & 22 & 7.1 \\
Dilovas1 & 3 & 2.5 & 7 & 2.2 \\
\hline Toplam & 121 & 100 & 308 & 100 \\
\hline
\end{tabular}

Araştırmaya katılan 308 okul yöneticisinin anketlerinin incelenmesi neticesinde toplam 5 yöneticinin anketi formun eksik doldurulması veya doldurulmaması nedeniyle değerlendirmeye alınmamış; toplam 303 yönetici anketi değerlendirilmiştir. Çalışmaya katılan okul yöneticilerinin cinsiyet ve görev durumuna ilişkin bilgiler Tablo 2'de verilmiştir.

Tablo 2. Katılımcıların Demografik Özelliklerine Göre Dağılımı

\begin{tabular}{llcc}
\hline Kişisel Özellikler & & $\mathbf{N}$ & $\mathbf{\%}$ \\
\hline Cinsiyet & Kadın & 82 & 27.1 \\
& Erkek & 229 & 72.9 \\
\hline Görev & Müdür & 121 & 39.9 \\
& Müdür Yardımcıs1 & 182 & 60.1 \\
\hline Kidem & $1-5$ y1l & 80 & 26.4 \\
& 6-10 y1l & 59 & 19.5 \\
& $11-15$ y1l & 71 & 23.4 \\
& 16 y1l ve üstü & 93 & 30.7 \\
\hline
\end{tabular}

Araştırmaya katılan okul yöneticilerinin 82'si (\%27.1) kadın, 221'i (\%72.9) ise erkektir. Okul yöneticilerinin görevlerine göre 121’i (\%39.9) müdür ve 182'si (\%60.1) müdür yardımcısıdır. 


\section{Verilerin Toplanması}

$\mathrm{Bu}$ araştırmada, okul yöneticilerinin duygusal zekâ yeterliklerini belirlemede Duygusal Yeterlik Ölçeği ve Dönüşümcü/Etkileşimci Liderlik düzeylerini belirlemede Çok Faktörlü Liderlik Ölçeği kullanılmıştır.

Duygusal Yeterlik Ölçeği: Bu araştırmada, duygusal zekâ yeterliklerini belirlemek için 1998 yılında Goleman tarafindan geliştirilen ve Türkçe uyarlaması Çamsarı (2007) tarafından yapılan Duygusal Yeterlik Ölçeği (Emotional Competence Inventory) kullanılmıştır. Duygusal Yeterlik Ölçeği; özbilinç, özyönetim, sosyal bilinç, ilişki yönetimi olmak üzere dört yeterliği ve bu yeterliklere ait toplam 18 alt boyutu içermektedir. Özbilinç yeterliği üç alt boyuttan (duygusal özbilinç, isabetli özdeğerlendirme ve özgüven) oluşmaktadır. Öz yönetim yeterliği 6 alt boyuttan (duygusal özdenetim, saydamlık, uyumluluk, başarma dürtüsü, iyimserlik ve inisiyatif) oluşmaktadır. Sosyal bilinç yeterliği 3 alt boyuttan (empati, örgütsel bilinç ve hizmet) ve ilişki yönetimi yeterliği ise 6 alt boyuttan (ekip çalışması ve imece, etkileme, başkalarını geliştirme, değişim katalizörlüğü ve çatışma yönetimi) oluşmaktadır.

Duygusal Yeterlik Ölçeği toplam 72 maddeden oluşan 5'li likert tipinde (0-Hiçbir zaman, 4-Her zaman) bir ölçektir. Ölçekte "Başkalarının katkılarını ısrarla talep ederim." ve "Duyguların davranışları nasıl etkilediğinin farkındayımdır." gibi maddeler yer almaktadır. Verilerin analizi sonucunda Duygusal Yeterlik Ölçeği'nin Cronbach Alfa güvenirlik katsayıs1 $\alpha=0.91$ olarak hesaplanmıştır. Duygusal yeterliklere ilişkin Cronbach Alfa güvenirlik değerleri sırasıyla özbilinç yeterliği için $\alpha=0.79$, özyönetim yeterliği için $\alpha=0.83$, sosyal bilinç yeterliği için $\alpha=0.78$ ve ilişki yönetimi yeterli-

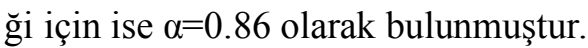

Ölçeğe ait KMO değeri (0.867), Bartlett Test of Sphericity değeri (9154.188), df (2556), $(p=0.000)$ bulunmuştur. KMO test değeri 0.5 'in üstünde ve Bartlett testi sonucu anlamlıdır $(p<0.05)$. Bu analizin ardından ölçeğin bütünü için varimax rotasyonu ile yapılan temel bileşen analizi sonucunda toplam varyansı açılama oranı 70.658 olan ve faktör yük değerleri (0.39) ile (0.76) arasında değişen toplam on sekiz boyut ortaya çıkmıştır. Faktör yapısına ilişkin analizler; ölçeğin toplam varyansın \%61.47'sini açıklayan özbilinç faktörü ( 3 alt boyut ve faktör yük değerleri 0.42-0.79 arasında değişen 12 madde); toplam varyansın \%62.13'ünü açıklayan özyönetim faktörü ( 6 alt boyut ve faktör yük değerleri 0.39-0.81 arasında değişen 24 madde), toplam varyansın \%63.54'ünü açıklayan sosyal bilinç faktörü (3 alt bo- 
yut ve faktör yük değerleri 0.40-0.79 arasında değişen 12 madde) ve toplam varyansın \%62.13'ünü açıklayan ilişki yönetimi faktöründen (6 alt boyut ve faktör yük değerleri 0.41-0.76 arasında değişen 24 madde) oluştuğunu göstermiştir.

Çok Faktörlü Liderlik Ölçeği: Çok Faktörlü Liderlik Ölçeği, Bass ile Avolio (1995) tarafından geliştirilmiş ve Karip (1998) tarafından Türkçeye uyarlanmıştır. Dönüşümcü ve etkileşimci liderlik ile liderlik davranışının sonuçlarını ölçmeyi hedefleyen toplam 45 maddeyi içermektedir. Ölçek 5'li likert tipindedir (0-Hiçbir zaman, 4-Her zaman) ve "Astların gösterdikleri çabalarının karşılı̆̆ 1 olarak onlara yardımcı olurum.”, "Dikkati düzensizlikler, hatalar, istisnalar ve standarttan sapmalar üzerinde yoğunlaştırırım." gibi maddeler içermektedir.

Çok Faktörlü Liderlik Ölçeği'nin bütününe ait Cronbach Alfa Güvenirlik Katsayısı $\alpha=0.93$, dönüşümcü liderlik alt boyutu için $\alpha=0.82$ ve etkileşimci liderlik alt boyutu için $\alpha=0.72$ olarak bulunmuştur.

KMO değeri (0.842), Bartlett Test of Sphericity değeri (3539.819), df (990), ( $p=.000$ ) bulunmuştur. KMO değeri 0.5'in üstünde olduğu için Bartlett testi sonucu anlamlıdır $(p<0.05)$. Bu değerlerin ardından ölçeğin bütünü için varimax rotasyonu ile yapılan temel bileşen analizi sonucunda ölçekte toplam varyansın \%63.99'unu açılayan ve faktör yük değerleri (0.41) ile (0.79) arasında olan dokuz boyut ortaya çıkmıştır. Bu analize göre bazı maddelerin faktör yük değerleri birbirine yakındır ve bazı maddeler ölçeğin orijinalinde yer alan boyutlarda değil başka boyutlar altında toplanmıştır. Ancak bu maddelerin faktör yük değerleri 0.41 ve üzerinde olduğu için ölçeğin orijinaline sadık kalınmıştır. Faktör yapısına ilişkin analizler; ölçeğin toplam varyansın \%61.21'ini açıklayan dönüşümcü liderlik faktörü (5 alt boyut ve faktör yük değerleri 0.41-0.80 arasında değişen 20 madde) ile toplam varyansın \%63.97'sini açıklayan etkileşimci liderlik faktöründen (4 alt boyut ve faktör yük değerleri $0.43-0.80$ arasında değişen 16 madde) oluştuğunu göstermiştir.

\section{Bulgular}

Araştırmanın yanıt aradığı ilk soru; okul yöneticilerin duygusal zekâ yeterliklerinin düzeyine ilişkindir. $\mathrm{Bu}$ araştırma sorusuna ilişkin tanımlayıcı istatistikler Tablo 3'de verilmiştir. 
Tablo 3. Okul Yöneticilerinin Duygusal Zekâ Yeterliklerine İlişkin Tanımlayıc1 İstatistikler

\begin{tabular}{lccl}
\hline Duygusal Zekâ Boyutları & $\mathbf{N}$ & $\overline{\boldsymbol{x}}$ & $\mathbf{s s}$ \\
\hline Özbilinç & 303 & $3.03^{\mathrm{a}}$ & .51 \\
Öz Yönetim & 303 & $2.77^{\mathrm{a}}$ & .43 \\
Sosyal Bilinç & 303 & $3.04^{\mathrm{a}}$ & .51 \\
İlişki Yönetimi & 303 & $2.91^{\mathrm{a}}$ & .53 \\
\hline Genel & 303 & $2.91^{\mathrm{a}}$ & .45 \\
\hline${ }^{a} 0=$ Hiçbir zaman, 4=Her zaman & & &
\end{tabular}

Tablo 3'e göre, okul yöneticilerinin duygusal zekâ yeterliklerine ait puan ortalamas1 2.91'dir. Alt boyutlara ait değerler incelendiğinde en yüksek değerin sosyal bilinç yeterliğine ait olduğu (3.04), özbilinç boyutuna ait ortalama puanın sosyal bilince yakın olduğu (3.03), en düşük değerin $\ddot{z} z$ yönetim yeterliğine (2.77) ait olduğu görülmektedir.

Okul yöneticilerinin duygusal zekâ yeterliklerinin cinsiyete göre farkl1lık gösterip göstermediğini belirlemek için $t$ testi uygulanmıştır. $\mathrm{Bu}$ alt probleme ilişkin bulgular Tablo 4'te verilmiştir.

Tablo 4'e göre kadın okul yöneticilerinin özbilinç yeterlik düzeyleri erkek yöneticilerin özbilinç yeterliğinden anlamlı düzeyde daha yüksektir $[\mathrm{t}(303)=2.90, p<0.01]$. Özbilincin alt boyutları itibarı ile; kadın yöneticilerin duygusal özbilinç [ $\mathrm{t}(303)=4.00, p<0.01]$ ve özgüven [t(303) $=2.77, p<0.05]$ yeterlikleri erkek okul yöneticilere göre anlamlı düzeyde daha yüksektir. İsabetli özdeğerlendirme düzeylerinde ise cinsiyete göre anlamlı bir farklılık yoktur $[\mathrm{t}(303)=0.59, p>0.05]$.

Duygusal zekânın ikinci alt boyutu olan öz yönetim yeterliliğinin cinsiyete göre anlamlı farklılık göstermediği görülmektedir [ $\mathrm{t}=0.86, p>0.05]$. Genel olarak duygusal özdenetim, saydamlık, başarma dürtüsü, iyimserlik boyutlarında kadın okul yöneticilerinin ortalama puanları daha yüksek; uyumluluk ve insiyatif alt boyutlarında erkek okul yöneticilerinin ortalama puanları kadın okul yöneticilerinin ortalamalarından daha yüksektir.

Kadın yöneticilerin duygusal zekânın üçüncü alt boyutu olan sosyal bilinç yeterlikleri erkek yöneticilere göre anlamlı derecede daha yüksektir $[\mathrm{t}(301)=2.03, p<0.05]$. Sosyal bilincin alt boyutlarından empati ve örgütsel bilinç alt boyutlarında cinsiyete göre anlamlı bir fark yoktur. Kadın yöneticilerin hizmet alt boyutundaki yeterlikleri ise erkek yöneticilere göre anlamlı düzeyde daha yüksektir [t(303) $=2.03, p<0.05]$. 
Tablo 4. Duygusal Zekâ Yeterliklerinin Cinsiyete Göre Karşılaştırılması

\begin{tabular}{|c|c|c|c|c|c|c|c|}
\hline Duygusal Yeterlikler & Boyutlar & Cinsiyet & $\mathbf{N}$ & $\bar{x}$ & ss & t & $p$ \\
\hline \multirow{8}{*}{ Özbilinç } & \multirow{2}{*}{$\begin{array}{l}\text { Duygusal } \\
\text { Özbilinç }\end{array}$} & Kadın & 82 & 3.47 & .37 & \multirow{2}{*}{$4.00^{* *}$} & \multirow{2}{*}{.00} \\
\hline & & Erkek & 221 & 3.09 & .60 & & \\
\hline & \multirow{2}{*}{$\begin{array}{l}\text { İsabetli } \\
\text { Özdeğerlendirme }\end{array}$} & Kadın & 82 & 2.84 & .47 & \multirow[b]{2}{*}{.59} & \multirow[b]{2}{*}{.56} \\
\hline & & Erkek & 221 & 2.78 & .61 & & \\
\hline & \multirow[t]{2}{*}{ Özgüven } & Kadın & 82 & 3.40 & .35 & \multirow{2}{*}{$2.77^{*}$} & \multirow{2}{*}{.01} \\
\hline & & Erkek & 221 & 3.10 & .70 & & \\
\hline & \multirow[t]{2}{*}{ Genel } & Kadın & 82 & 3.24 & .31 & \multirow{2}{*}{$2.90^{* *}$} & \multirow{2}{*}{.00} \\
\hline & & Erkek & 221 & 2.99 & .54 & & \\
\hline \multirow{14}{*}{$\begin{array}{l}\text { Öz } \\
\text { Yönetim }\end{array}$} & Duygusal & Kadın & 82 & 2.65 & .71 & \multirow{2}{*}{1.67} & \multirow[b]{2}{*}{.10} \\
\hline & Özdenetim & Erkek & 221 & 2.45 & .74 & & \\
\hline & \multirow[t]{2}{*}{ Saydamlık } & Kadın & 82 & 3.09 & .50 & \multirow{2}{*}{1.43} & \multirow{2}{*}{.15} \\
\hline & & Erkek & 221 & 2.94 & .62 & & \\
\hline & \multirow[t]{2}{*}{ Uyumluluk } & Kadın & 82 & 2.90 & .46 & \multirow{2}{*}{-.61} & \multirow{2}{*}{.54} \\
\hline & & Erkek & 221 & 2.97 & .63 & & \\
\hline & Başarma & Kadın & 82 & 3.04 & .37 & & \\
\hline & Dürtüsü & Erkek & 221 & 2.94 & .64 & 1.01 & .31 \\
\hline & İyimserlik & Kadın & 82 & 3.28 & .54 & 03 & 35 \\
\hline & & Erkek & 221 & 3.17 & .70 & .93 & .35 \\
\hline & İnisiyatif & Kadın & 82 & 1.97 & .34 & & \\
\hline & & Erkek & 221 & 2.09 & .55 & -1.40 & .16 \\
\hline & Genel & Kadın & 82 & 2.82 & .35 & & \\
\hline & & Erkek & 221 & 2.76 & .45 & .86 & .39 \\
\hline & Empati & Kadın & 82 & 3.31 & .49 & 105 & \\
\hline & & Erkek & 221 & 3.12 & .65 & 1.85 & .06 \\
\hline & Örgütsel & Kadın & 82 & 2.63 & .48 & & \\
\hline & Bilinç & Erkek & 221 & 2.50 & .64 & 1.27 & .21 \\
\hline Sosyal Bilinç & Hizmet & Kadın & 82 & 3.55 & .30 & & \\
\hline & & Erkek & 221 & 3.36 & .61 & $2.01^{*}$ & .04 \\
\hline & Genel & Kadın & 82 & 3.16 & .30 & $03 * *$ & \\
\hline & & Erkek & 221 & 2.99 & .54 & 2.03 & .04 \\
\hline & Ekip Çalışması & Kadın & 82 & 3.08 & .61 & & \\
\hline & ve İmece & Erkek & 221 & 2.97 & .69 & .99 & .32 \\
\hline & Etkileme & Kadın & 82 & 2.91 & .60 & 12 & 26 \\
\hline & & Erkek & 221 & 2.77 & .75 & 1.13 & .26 \\
\hline & Başkalarını & Kadın & 82 & 3.20 & .42 & & \\
\hline & Geliştirmek & Erkek & 221 & 3.10 & .64 & .94 & .35 \\
\hline İlişki & Değişim & Kadın & 82 & 3.19 & .58 & & \\
\hline Yönetimi & Katalizörlüğü & Erkek & 221 & 2.95 & .70 & $2.10^{* *}$ & .04 \\
\hline & Çatışma & Kadın & 82 & 2.63 & .46 & $10 ?$ & \\
\hline & Yönetimi & Erkek & 221 & 2.72 & .52 & -1.02 & .31 \\
\hline & Esin Verici & Kadın & 82 & 2.85 & .69 & & \\
\hline & Liderlik & Erkek & 221 & 2.87 & .88 & -.13 & .89 \\
\hline & Genel & Kadın & 82 & 2.98 & .40 & 90 & 37 \\
\hline & & Erkek & 221 & 2.90 & .55 & .90 & .31 \\
\hline Genel & & Kadın & 82 & 3.00 & .33 & 252 & 11 \\
\hline Genel & & Erkek & 221 & 2.89 & .47 & 2.52 & .11 \\
\hline
\end{tabular}


Duygusal zekânın dördüncü alt boyutu olan ilişki yönetimi yeterliliğininde cinsiyete göre anlamlı bir fark ortaya çıkmamıştır $[\mathrm{t}(303)=0.90$, $p>0.05$ ]. İlişki yönetiminin alt boyutlarından yalnızca değişim katalizörlüğü alt boyutunda kadın yöneticiler lehine anlamlı bir fark bulunmuştur $[\mathrm{t}(303)=2.10, p<0.05]$. Ekip çalışması ve imece, etkileme, başkalarını geliştirmek boyutlarında kadın yöneticilerin puanları; çatışma yönetimi ve esinleyici liderlik alt boyutlarında erkek yöneticilerin puanları daha yüksek olmakla birlikte farklar anlamlı değildir. Alt boyuta ilişkin genel ortalama değerler dikkate alındığında kadın yöneticilerin ortalama puanları erkek yöneticilerdan daha yüksektir.

Araştırmanın ikinci problemi, okul yöneticilerinin duygusal zekâ yeterliklerinin dönüşümcü ve etkileşimci liderliği ne düzeyde yordadığıdır. Bu amaçla, LISREL yazılım programı kullanılarak gerçekleştirilen yol analizine ilişkin bulgular Şekil 1'de verilmiştir.

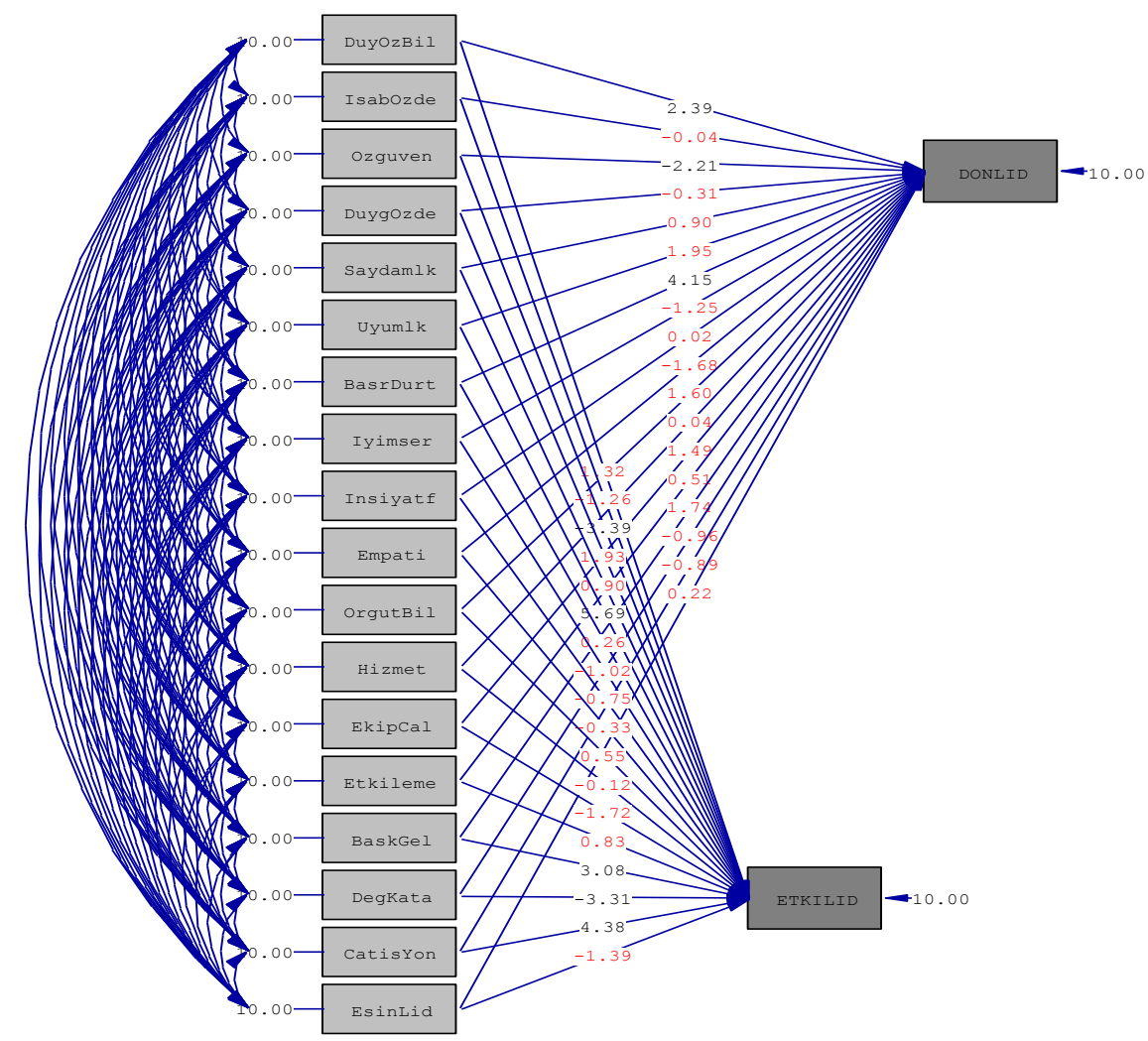

Şekil 1. Duygusal zekâ yeterliklerinin liderlik stilleri üzerindeki etkisini gösteren yapısal eşitlik grafiği. 
Şekil 1'de, okul yöneticilerinin duygusal zekâ yeterliklerinin liderlik stilleri üzerindeki etkisine ilişkin $t$ değerleri görülmektedir. Buna göre; duygusal özbilinç ( $\mathrm{t}=2.39)$ ve başarma dürtüsünün $(\mathrm{t}=4.15)$ dönüşümcü liderlik üzerinde anlamlı ve olumlu etkisi; özgüvenin ise anlamlı ( $\mathrm{t}=-2.21)$ ve olumsuz bir etkisi vardır. Başarma dürtüsünün dönüşümcü liderlik üzerindeki etkisi diğer alt boyutlara göre daha güçlüdür. Duygusal zekâ yeterliklerinin etkileşimci liderlik üzerindeki etkisi incelendiğinde ise; uyumluluk ( $\mathrm{t}=5.69)$, çatışma yönetimi $(t=4.38)$ ve başkalarını geliştirmek $(t=3.08)$ yeterliklerinin etkileşimci liderliği anlamlı düzeyde olumsuz etkilediği; özgüven ( $\mathrm{t}=-3.39)$ ve değişim katalizörlüğünün ( $\mathrm{t}=-3.31)$ etkisinin ise anlamlı düzeyde olumsuz olduğu görülmektedir. Uyumluluk alt boyutunun etkileşimci liderlik üzerindeki etkisi diğer boyutlara göre daha güçlüdür.

Okul yöneticilerinin duygusal zekâ yeterliklerinin liderlik stilleri üzerindeki yordayıcı etkisine ilişkin regresyon katsayılarını belirlemek için LISREL kullanılarak yapılan regresyon analizine ilişkin bulgular Tablo 5'de verilmiştir.

Tablo 5. Regresyon Analizi Katsayıları (Duygusal Zekâ - Liderlik)

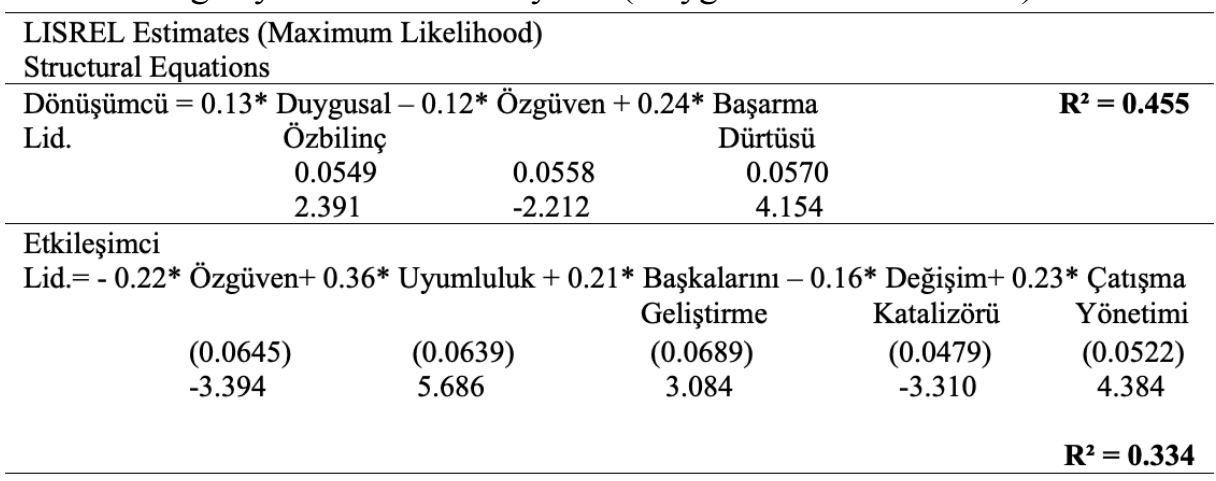

Tablo 5'e göre duygusal zekâ alt boyutlarından duygusal özbilinç ve başarma dürtüsü dönüşümcü liderliği pozitif yönde, özgüven ise negatif yönde etkilemektedir. Duygusal özbilinç düzeyindeki 1 puanlık artış dönüşümcü liderlik düzeyini ortalama 0.13 puan artırmaktadır. Başarma dürtüsü düzeyindeki 1 puanlık artışın dönüşümcü liderlik düzeyi üzerindeki etkisi 0.24 puanlık artış biçiminde ortaya çıkmaktadır. Diğer yandan, özgüvendeki artış dönüşümcü liderlik düzeyini ortalama 0.12 puan azaltmaktadır. Bu sonuçlara göre dönüşümcü liderlik üzerinde en etkili duygusal zekâ alt boyutunun başarma dürtüsü olduğu söylenebilir. $\mathrm{R}^{2}$ değerlerine göre üç boyut 
birlikte dönüşümcü liderliği yaklaşık olarak \%46 düzeyinde açıklamaktadır.

Etkileşimci liderliğe ilişkin sonuçlara göre; uyumluluk, başkalarını geliştirme ve çatışma yönetimi etkileşimci liderliği pozitif yönde, özgüven ve değişim katalizörlüğü ise negatif yönde etkilemektedir. $\mathrm{Bu}$ alt boyutlar arasında en güçlü etki uyumluluğun etkileşimci liderlik üzerindeki etkisidir (0.36). Özgüvenin etkileşimci liderlik üzerindeki etkisi olumsuzdur. Başkalarını geliştirme ve çatışma yönetimi etkileşimci liderliği olumlu etkilerken değişim katalizörlüğünün etkisi olumsuzdur. $\mathrm{R}^{2}$ değerine göre beş boyut birlikte etkileşimci liderliği yaklaşık olarak \%33 düzeyinde açıklamaktadır.

\section{Tartışma ve Sonuç}

Mevcut araştırma, ilk ve ortaöğretim düzeyindeki okullarda görev yapan yöneticilerin duygusal zekâ yeterliklerini ve bu yeterliklerin cinsiyete göre anlamlı bir farklılık gösterip göstermediğini incelemeyi ve duygusal zekâ yeterliklerinin dönüşümcü ve etkileşimci liderlik düzeylerini ne ölçüde yordadığını tespit etmeyi amaçlamaktadır.

Duygusal zekâ yeterliklerine ait ortalama puanlar incelendiğinde okul yöneticilerinin yüksek sayılabilecek düzeyde duygusal zekâ yeterliğine sahip oldukları görülmektedir. Bu sonuç, Altıntaş'ın (2009) Isparta'da ilkokul yöneticileri üzerindeki çalışmasında ulaştığı sonuca ve Çamsarı'nın (2007) İzmir'de ilköğretim okulu müdürleri üzerindeki çalışmasında elde ettiği sonuca oldukça yakındır.

Mevcut çalışmada ve anılan iki çalışmada (Altıntaş, 2009; Çamsarı, 2007) alt yeterliklere ilişkin olarak benzer sonuçlar elde edilmiş olması dikkat çekicidir. Her üç araştırmada da okul yöneticilerinin sosyal bilinç yeterliklerine ait puan ortalaması diğer boyutlara kıyasla daha yüksek ve öz yönetim yeterliklerine ait puan ortalaması ise diğer yeterliklere kıyasla daha düşüktür. Sosyal bilinç, bireyin sosyal çevresi ile ilişkilerini nasıl ele aldığııı belirler. Yöneticiler açısından; ahenk yaratma, başkalarının hislerinin farkında olma ve bunları yönetebilme gibi yeterliklerle ilişkilendirilebilir. Öz yönetim ise bireyin duygularını yönetebilme, kaygı ve öfke gibi sıkıntı verici durumları düzenleme ve duygusal dürtülere hâkim olabilme yeteneğidir. Üç çalı̧̧mada da okul yöneticilerinin sosyal bilinç yeterliğinin diğer boyutlara kıyasla yüksek, öz yönetim yeterliğinin ise düşük çıkması Türk kültürünün toplulukçu eğilimi ile ilişkilendirilebilir. Topluluk yönelimli kültürlerde gruba aidiyet ve grup uyumu gibi öncelikler bireyin önceliklerinin önüne geçer (Hofstede, 1980). Bu eğilimin bir sonucu olarak, okul yöneticilerinin 
ahenk yaratma, başkalarının hislerinin farkında olma ve bunları yönetme gibi yeteneklerinin özyönetim gibi birey odaklı yeteneklere kıyasla daha gelişmiş olabileceği akla gelmektedir.

Araştırmanın ikinci önemli bulgusu, kadın okul yöneticilerinin genel duygusal zekâ yeterliklerinin erkek yöneticilere göre daha yüksek olduğu bulgusudur. Duygusal zekânın özbilinç ve sosyal bilinç yeterlikleri bak1mından kadın okul yöneticileri lehine anlamlı fark mevcuttur. Özyönetim ve ilişki yönetiminde ise fark önemsiz ancak yine kadınlar lehine yüksektir. Yeterliklerin alt boyutlarından kadınlar lehine anlamlı farklılık bulunanlar ise duygusal özbilinç, özgüven, hizmet ve değişim katalizörlüğüdür.

Elde edilen sonuç, genel olarak kadınların duygusal zekâ düzeyinin erkeklerden daha yüksek olduğunu gösteren alanyazın ile uyumludur (örn. Ciarrochi, Chan ve Caputi, 2000; Dawda ve Hart, 2000; Extremera, Fernandez-Berrocal ve Salovey, 2006; Mayer, Caruso ve Salovey, 1999; Wolf, 2005). Duygusal zekâ alt boyutlarının cinsiyete göre ne şekilde farklılaştığı konusunda ise alanyazında görüş birliği bulunmadığı yukarıda ifade edilmişti. Örneğin Bar-On ve arkadaşları (2000) kadınların ilişki yönetimi yeterliklerinin erkeklerden daha yüksek olduğunu, ancak erkeklerin stresle başa çıkmada daha başarılı olduklarını ifade etmektedir. Bazı çalışmalarda kadınların duyguları algılamada erkeklerden daha başarılı oldukları (Ciarrochi, Chan ve Caputi, 2000; Mayer ve Geher, 1996; Wong ve Law, 2002), duygularından daha fazla şüphe duydukları ve aklı daha geri planda tuttukları (Quader, 2011) bulunmuştur. Diğer bazı çalışmalarda ise, kadınların sosyal bilinç yeterliğinin (Wolf, 2005) ve uyumluluk ile hizmet yeterliklerinin (Cavallo ve Brienza, 2004) erkeklere kıyasla daha yüksek olduğu sonucuna ulaşılmıştır.

Tartışılan sonuçlar ışığında kadın okul yöneticilerinin duygusal zekâ yeterliklerinin erkek okul yöneticilerine kıyasla genel olarak daha yüksek olduğu iddia edilebilir. Ancak farklılaşmanın hangi boyutlarda olduğu konusunda sonuçların birbiri ile tutarlı olmaması, durumsal değişkenlerin bazı yeterliklerin ön plana çıkmasında etkili olabileceğini akla getirmektedir. $\mathrm{Bu}$ nedenle kadın yöneticilerin duygusal zekâ alt boyutları konusunda ilave çalışmalara ihtiyaç bulunmaktadır.

Araştırmanın üçüncü önemli bulgusu, duygusal zekânın dönüşümcü liderliği (\%46) ve etkileşimci liderliği (\%33) anlamlı düzeyde açıkladığı bulgusudur. Duygusal zekâ ile liderlik arasındaki ilişkiyi inceleyen çalışma- 
larda duygusal zekânın genel olarak liderlik performansı üzerinde (örneğin Packard, 2008; Samad, 2009), özelde ise etkileşimci ve dönüşümcü liderlik üzerinde etkili olduğu bulunmuştur (Barbuto ve Burbach, 2006; Barling, Slater ve Kelloway, 2000; Corona, 2010; Gardner ve Stough, 2002; Mandell ve Pherwani, 2003; Rajagopalan, 2009). Bu etkiyi karşılaştıran çalışmalarda duygusal zekânın dönüşümcü liderlik üzerindeki etkisinin daha güçlü olduğu ve duygusal zekânın dönüşümcü liderliği yordama düzeyinin etkileşimci liderliği yordama düzeyine göre daha yüksek olduğu ortaya konmuştur (Jerome, 2009; Rajagopalan, 2009). Bu sonuçlara göre mevcut araştırmanın bulguları genel olarak alanyazın ile uyumludur.

Mevcut araştırmanın sonuçlarına göre başarma dürtüsü ile duygusal özbilinç dönüşümcü liderliğin güçlü bir yordayıcısıdır. Başarma dürtüsü zayıf bireylerin yüksek düzeyde dönüşümcü liderlik sergilemesi, cazip bir vizyon ortaya koyarak izleyicilerde bu ortak amaç konusunda aşkın bir bağl11ık ve adanmışlık oluşturabilmesi mümkün değildir. Diğer yandan, duygusal özbilincin dönüşümcü liderliği açıklayan diğer bir önemli duygusal yeterlik olması da beklentilere uygun bir sonuçtur. Duygusal özbilinç bireyin kendi duygularının, güçlü-zayıf yanlarının farkında olması ve duygularını sosyal olarak kabul edilebilir biçimlerde ifade edebilmesi ile ilişkilidir. Bu tür yeterlikler dönüşümcü liderlerin çalışanlar üzerinde güçlü bir etki kurabilmesi açısından önemlidir. Özgüvenin dönüşümcü liderlik üzerindeki etkisinin olumsuz olması ise beklenmedik bir sonuçtur.

Duygusal zekânın etkileşimci liderliği yordama düzeyine ilişkin olarak ise uyumluluk, başkalarını geliştirme ve çatışma yönetiminin etkileşimci liderliği anlamlı düzeyde açıkladığı bulunmuştur. Özgüven ve değişim katalizörlüğünün etkisi ise olumsuzdur. Uyumluluğun etkileşimci liderlik üzerindeki etkisi başkalarını geliştirme ve çatışma yönetiminin etkisine göre daha güçlüdür ( $\mathrm{t}=0.36)$. Uyumluluk, başkalarını geliştirme ve çatışma yönetimi gibi yeterliklerin ön plana çıkarılması etkileşimci liderliğin daha çok takas temelli bir liderlik biçimi olması ile ilişkilendirilebilir. Değişim katalizörlüğünün etkisinin olumsuz olması da bu tezi desteklemektedir. Etkileşimci liderlik, değişim ve yenilik odaklı bir liderlik biçimi olan dönüşümcü liderliğin aksine daha çok statükoyu sürdürme odaklı bir liderlik tarzıdır.

Özgüvenin hem dönüşümcü hem etkileşimci liderlik üzerindeki etkisinin olumsuz olması beklenmedik ve ilginç bir bulgudur. Özgüven liderlerin en başta gelen özelliklerinden biri olarak kabul edilmektedir. Elde edilen 
sonuç, Türk liderlik yazınında özgüvenin daha dikkatli ele alınması ve daha derinlemesine araştırılması gereğini akla getirmektedir. Zira tevazuun önemli bir değer olarak kabul edildiği Türk toplumunda yüksek düzeyde özgüvenin kibir, kendini beğenme gibi olumsuz birtakım tutum/duygularla ilişkilendirilmesi olasidir.

Duygusal gelişim büyük oranda erken çocukluk yaşlarında gerçekleşirken birtakım yeterliklerin (örn. duygusal özdenetim, algılama ve tepkiyi düzenleme) merkezi olan beyindeki ön loblar 16 ve 18 yaşlarına kadar gelişebilmektedir (Goleman, 2005b). Bu yaştan sonraki gelişme ancak kişinin değişme isteğinin çok güçlü olmasına bağlıdır ve uzun sürede gerçekleşebilmektedir. Bu nedenle okul yöneticilerinin duygusal zekâ düzeylerini geliştirmek için profesyonel eğitim programları düzenlenmesi okullarda liderlik, iletişim, empati başta olmak üzere birçok sürecin niteliğinin geliştirilmesine olumlu katkılar sağlayabilir. Okullardaki iletişimin ve empatinin gelişmesi okul iklimi ve kültürünü olumlu etkileyerek öğrenme-öğretme süreçlerinin geliştirilmesine katkı sağlayabilir.

Kadınların daha yüksek düzeyde gösterdiği ihtiyaçları fark etme, karş1lama, besleyici olma, kendilerini rahat hissetme, hissettirme ve dengeli davranma gibi özellikler giderek daha kritik ve talep edilir hâle gelmektedir (Baltaş, 2013). Bu nedenle önümüzdeki yıllarda kadın yöneticilerin birçok alanda olduğu gibi okul yönetiminde de ağırlıklarını daha fazla hissettirmeye başlayacağı öngörülebilir. Duygusal zekâ avantajları ve diğer özellikleri düşünüldüğünde bu durum okul yönetimi açısından olumlu bir gelişme olacaktır.

Özgüvene ilişkin bulgular dikkate alındığında özgüvenin ne şekilde dışa vurulduğuna ve çalışanlarca nasıl algılandığına ilişkin ilave araştırmalara ihtiyaç olduğu ifade edilebilir. Özgüvenin liderlik sürecindeki etkisini kültürel farklılıklar bağlamında inceleyen araştırmalar bu ilişkinin daha iyi anlaşılmasını sağlayabilir.

Mevcut araştırmanın en önemli sınırlılığı verilerin yalnızca okul yöneticilerinin değerlendirmelerine dayalı olması nedeniyle ortak yöntem varyansı olasılığıdır. Ortak yöntem varyansının etkilerini sınırlamak için farklı kaynaklardan veri toplama en etkili çözümdür. Bu kapsamda mevcut araştırmanın, farklı kaynaklardan toplanan verilerle ve daha büyük örneklemler üzerinde tekrarlanması yararlı olabilir. 


\section{Kaynakça}

Acar, F. (2002). Duygusal zekâ ve liderlik. Erciyes Üniversitesi Sosyal Bilimler Enstitüsü Dergisi, 12, 53-68.

Altıntaş, Ö. C. (2009). Duygusal zeka elemanlarının liderlik tarzları ve örgütsel sonuçlar üzerindeki etkisi, Isparta ili ilköğretim okullarında bir uygulama. Yayınlanmamış doktora tezi, Gebze Yüksek Teknoloji Enstitüsü.

Antonakis, J., Ashkanasy, N. M. ve Dasborough, M. T. (2009). Does leadership need emotional intelligence? The Leadership Quarterly, 20, 247-261.

Doi: 10.1016/j.leaqua.2009.01.006

Baltaş, A. (2013). Türk kültüründe yönetmek (6. bask1). Ankara: Remzi Kitabevi.

Barbuto, J. E. ve Burbach, M. E. (2006). The emotional intelligence of transformational leaders: A field study of elected officials. The Journal of Social Psychology, 146(1), 51-65.

Bar-On, R., Brown, J. M., Kirkcaldy, B. D. ve Thome, E. P. (2000). Emotional expression and implications for occupational stress: An application of the Emotional Quotient Inventory (EQ-i). Personality and Individual Differences, 28(6), 1107-1118.

Barling, J., Slater, F. ve Kelloway, E. K. (2000). Transformational leadership and emotional intelligence, an exploratory study. Leadership and Organizational Journal, 21(3), 157-161.

Bass, B. M. (1990). From transactional to transformational leadership: learning to share the vision. Organizational Dynamics, 18, 19-31.

Bass, B. M. ve Avolio, B. J. (1995). MLQ multifactor qeadership Questionnaire, leader form, rater form, and scoring. California. Palo Alto, CA: Mind Garden.

Boyatzis, R. E., Goleman, D. ve Rhee, K. (2000). Clustering competence in emotional intelligence, insights from the emotional competence inventory (ECI). R. Bar-On ve J. D. A. Parker, (Ed.), Handbook of emotional intelligence içinde (343-362). San Francisco: Jossey-Bass.

Can, A. (2014). SSPS ile bilimsel araşttrma sürecinde nicel veri analizi (2. 
bask1). Ankara: Pegem Akademi.

Cavallo, K. ve Brienza, D. (2004). Emotional competence and leadership excellence at Johnson \& Johnson: the emotional intelligence and leadership study. http://www.eiconsortium.org/pdf/jj_ei_study.pdf

Ciarrochi, J. V., Chan, A. Y. C. ve Caputi, P. (2000). A critical evaluation of the emotional intelligence construct. Personality \& Individual Differences, $28,539-561$.

Corona, M. A. (2010). The relationship between emotional intelligence and transformational leadership. The Business Journal of Hispanic Research, 4(1), 22-34.

Çakar, U. ve Arbak, Y. (2003). Dönüşümcü liderlik duygusal zeka gerektirir mi? Yöneticiler üzerinde örnek bir çalışma. D.E.Ü.İI.I.B.F. Dergisi, 18(2), 83-92.

Çamsarı, A. T. (2007). İlköğretim okulu müdürlerin duygusal zeka ve ögrretmenlerin iş doyum düzeyleri. Yayınlanmamış doktora tezi, Dokuz Eylül Üniversitesi Eğitim Bilimleri Enstitüsü.

Çiğdem, A. (1997). Aydınlanma düşüncesi. İstanbul: İletişim Yayınları.

Dawda, D. ve Hart, S. D. (2000). Assessing emotional intelligence: Reliability and validity of the Bar-On Emotional Quotient Inventory (EQ-I) in university students. Personality and Individual Differences, 28(4), 797-812.

Den Hartog, D. N., Van Muijen, J. J. ve Kopman, P. L. (1997). Transactional versus transformational leadership: An analysis of the MLQ. Journal of Occupational and Organizational Psychology, 70(1), 18-32.

Dulewicz, V. ve Higgs, M. (2003). Leadership at the top, the need for emotional intelligence in organizations. International Journal of Organizational Analysis, 11, 193-210.

Erkuş, A. ve Günlü, E. (2008). Duygusal zekânın dönüşümcü liderlik üzerine etkileri. Dokuz Eylül Üniversitesi İşletme Fakültesi Dergisi, 9(2), 187-209.

Extremera, N., Fernandez-Berrocal, P. ve Salovey, P. (2006). Spanish version of the Mayer-Salovey-Caruso Emotional Intelligence test 
(MSCEIT). Version 2.0: Reliabilities, age and gender differences. Psicothema, 18, 42-48.

Gardner, L. ve Stough, C. (2002). Examining the relationship between leadership and emotional intelligence in senior level managers. Leadership and Organization Development Journal, 23(1/2), 68-79.

George, J. M. (2000). Emotions and leadership, the role of emotional intelligence. Human Relations, 53(8), 1027-1055.

George, J. M. ve Bettenhausen, K. (1990). Understanding prosocial behavior, sales performance, and turnover, A group level analysis in a service context. Journal of Applied Psychology, 75, 698-709.

Goleman, D. (1998). Working with emotional intelligence. New York: Bantam Books.

Goleman, D., Boyatzis, R. E. ve McKee, A. (2002). Yeni liderler. (F. Nayır ve O. Deniztekin, Çev.). İstanbul: Varlık Yayınları. (Orijinal çalışma basım tarihi 1995.)

Goleman, D. (2005a). Duygusal zekâ. (B. S. Yüksel, Çev.). İstanbul: Varlık Yayınları. (Orijinal çalışma basım tarihi 1995.)

Goleman, D. (2005b). Yıkıcı duygular ile nasıl başa çıkabiliriz. (S. Hauser, Çev.). İstanbul: İnkılâp Kitabevi. (Orijinal çalışma basım tarihi 2004.)

Goleman, D. (2007). İş başında duygusal zekâ. (H. Balkara, Çev.). İstanbul: Varlık Yayınları. (Orijinal çalışma basım tarihi 2000.)

Higgs, M. ve Rowland, D. (2001). Developing change leaders: Assessing the impact of a development programme. Journal of Change Management, 2(1), 47-64.

Doi: $10.1080 / 714042485$

Hofstede, G. (1980). Culture's consequences: International differences in work-related values. Newbury Park, CA: Sage.

İşliel, K. (2013). Duygusal zeka ve liderlik. Yayınlanmamış yüksek lisans tezi, Dokuz Eylül Üniversitesi Eğitim Bilimleri Enstitüsü.

Jerome, K. L. (2009). An examination of the relationship between emotional intelligence and the leadership styles of early childhood. Yayınlanmamış doktora tezi, University of Oklahama Graduate College. 
Karasar, N. (2007). Bilimsel araştırma yöntemi (17. baskı). Ankara: Nobel.

Karip, E. (1998). Dönüşümcü liderlik. Kuram ve Uygulamada Eğitim Yönetimi, 3(16), 443-465.

Krishnan, V. R. (2005). Leader-member exchange, transformational leadership, and value system. Electronic Journal of Business Ethics and Organization Studies, 10(1).

http://ejbo.jyu.fi/pdf/ejbo_vol10_no1_pages_14-21.pdf

Kuşaklı, B. Y. (2008). Yönetici hemşirelerin duygusal zekâ yetenekleri ve liderlik davranışları. Yayınlanmamış yüksek lisans tezi, Marmara Üniversitesi Sağlık Bilimler Enstitüsü.

Leban, W. ve Zulauf, C. (2004). Linking emotional intelligence abilities and transformational leadership styles. Leadership and Organization Development Journal, 25, 554-64.

Lindenbaum, D. ve Cartwright, S. (2010). A critical examination of the relationship between emotional intelligence and transformational leadership. Journal of Management Studies, 47(7), 1317-1342.

Mandell, B. ve Pherwani, S. (2003). Relationship between emotional intelligence and transformational leadership style: A gender comparison. Journal of Business and Psychology, 17(3), 387-404.

Mayer, J. D., DiPaola, M. ve Salovey, P. (1990). Perceiving affective content in ambiguous visual stimuli: a component of emotional intelligence. Journal Of Personality Assessment, 54, 772-781.

Mayer, J. D. ve Geher, G. (1996). Emotional intelligence and the identification of emotion. Intelligence, 22, 89-113

Mayer, J. D., Caruso, D. R. ve Salovey, P. (1999). Emotional intelligence meets traditional standards for an intelligence. Intelligence, 27(4), 267-298.

Omar, Z., Zainal, A., Omar, F. ve Khairudin, R. (2009). The influence of leadership behaviour on organisational citizenship behaviour in self managed work teams in Malaysia. SA Journal of Human Resource Management, 7(1), 196-206.

Doi: 10.4102/sajhrm.v7i1.209

Özer, İ. Ç. (2010). Duygusal zekâ ile liderlik tarzları arasındaki ilişsi. Ya- 
yınlanmamış yüksek lisans tezi, Marmara Üniversitesi Sosyal Bilimler Enstitüsü.

Packard, J. A. (2008). Analyzing the intersection of leadership practices, emotional intelligence, and coping responses in women-owned small businesses: A case study. Yayınlanmamış doktora tezi, Capella University School of Business.

Poskey, M. (2006). The importance of emotional intelligence in the workplace, why it matters more than personality, http://www.irmi.com/expert/articles/2013/poskey09-employee-hiringdevelopment-retention.aspx

Quader, M. S. (2011). Leadership style and emotional intelligence: A gender comparison. Annamalia International Journal of Business Studies \& Research, 1(1), 1-23.

Rajagolapan, S. (2009). Relationship between emotional intelligence and transformational, transactional, and laissez-faire leadership styles of information systems project managers in virtual teams. Yayınlanmamış doktora tezi, Capella University School of Business \& Techno$\log$.

Salovey, P. ve Mayer, J. D. (1990). Emotional intelligence. Imagination, cognition, and personality, 9, 185-211.

Samad, S. (2009). The influence of emotional intelligence on effective leadership among managers in Malaysian business organizations. The Business Review, 13(1), 164-170.

Spaeth, K. S. (2007). School administrators: Leadership and emotional intelligence. Yayınlanmamış yüksek lisans tezi, Nippising University School of Graduate Studies.

Weinberger, L. A. (2003). An examination of the relationship between emotional intelligence, leadership style and perceived leadership effectiveness. Minnesota, Human Resource Development Research Center.

Wolf, S. B. (2005). Emotional competence inventory (ECI) technical manual. Hay Group, McClelland Center For Research and Innovation. http://www.eiconsortium.org/pdf/ECI_2_0_Technical_Manual_v2.pdf 
Wong, C. S. ve Law, K. S. (2002). The effects of leader and follower emotional intelligence on performance and attitude: An exploratory study. The Leadership Quarterly, 13, 243-274.

Yuk1, G. (2012). Leadership in organizations (8. bask1). New Jersey: Pearson. 